\title{
FREQUENCY OF PATHOGENIC FUNGI ON ALFALFA SEED OF DIFFERENT AGE
}

\section{Krnjaja ${ }^{1}$, J. Lević ${ }^{2}$ D. Ivanović ${ }^{2}$, V. Mandić ${ }^{1}$, Z. Tomić ${ }^{1}$, Z. Bijelić ${ }^{1}$, G. Marinkov ${ }^{1}$}

${ }^{1}$ Institute for Animal Husbandry, Autoput 16, P. Box 23, 11080, Belgrade-Zemun, Republic of Serbia

${ }^{2}$ Maize Research Institute „Zemun Polje”, Slobodana Bajića 1, 11185, Belgrade-Zemun, Republic of Serbia

Corresponding author: vesnakrnjaja.izs@gmail.com

Original scientific paper

Abstract: The presence of pathogenic fungi species on seed of six alfalfa cultivars (K-22, K-23, K-28, NS Banat, NS Mediana and Zaječarska 83) of different seed age (24 months and 108 months) was analyzed in this study. In studied cultivars, except in K-28, on older seeds, less fungi genera were identified compared to younger seed. Seven fungi genera were identified: Alternaria, Aspergillus, Cladosporium, Fusarium, Penicillium, Rhizopus, Stemphylium and sterile mycelia present in percentage from 0 to $6.5 \%$. Alternaria species were identified on younger seed with $0.5 \%$ in cultivars K-28 and NS Mediana, $0.75 \%$ in K-22, $1 \%$ in Zaječarska 83 and $1.25 \%$ in cultivar NS Banat. In cultivar K-28, Alternaria species were identified in percentage of $0.25 \%$ on older seed. Aspergillus species in percentage of $0.25 \%$ were identified only in younger seed of cultivar NS Mediana. Cladosporium species were identified on younger seed in the percentage of $0.25 \%$ (NS Mediana), $1 \%$ (K-23 and NS Banat) and $6.5 \%$ (K-22), and on older seed in percentage of $0.5 \%(\mathrm{~K}-23, \mathrm{~K}-28$ and NS Banat). Genus Fusarium was identified in percentage of $0.25 \%$ on younger seed of cultivar K-22. Genus Penicillium was identified in the range from $0.25 \%(\mathrm{~K}-22)$ to $0.5 \%(\mathrm{~K}-28)$ on younger seed and from $0.25 \%(\mathrm{~K}-22)$ to $1.75 \%$ (NS Banat) on older seed. Genus Rhizopus was identified in cultivar K-28, on younger $(0.5 \%)$ and older seed $(0.25 \%)$, and in cultivar Zaječarska 83 , only in younger seed with $0.5 \%$. Sterile mycelia was identified on younger seed of cultivars K-22 (4.5\%), NS Banat (1.75\%), K-23 (1.0\%) and Zaječarska $83(0.5 \%)$, and on older seed of cultivars K23 and K-28 with $0.25 \%$ and K-22 with $0.5 \%$. Genus Stemphylium was identified in percentage of $0.25 \%$ only on younger seed of cultivars K-22, K-23, NS Banat and NS Mediana. Results of these analysis indicated favourable health condition of seeds of different age of analyzed alfalfa cultivars, especially in relation to economically important fungi genera Fusarium and Stemphylium.

Key words: seed, alfalfa, cultivars, pathogenic fungi 


\section{Introduction}

Considering that livestock production in Serbia is one of the most important branches of agriculture, it should be expected that adequate attention is focused on production of high quality livestock food. Among forage plants used in animal nutrition, alfalfa is the most important, hence it is often called »queen of forage plants «. As one of the oldest and most important perennial forage plants, it has very high yields and provides livestock food of excellent quality (Krnjaja, 2005).

Alfalfa is wide spread in plant production in Serbia, due to favourable agro-ecological conditions for its growing. Total area under alfalfa in 2009 was 188.008 ha, of which in Central Serbia it was grown on 133.010 ha, and in Vojvodina on 54.998 ha (Statistički godišnjak Srbije, 2010). However, production of alfalfa seed in some years doesn't satisfy the domestic needs, therefore the seed is imported (Karagić et al., 2007) or older seed stored in warehouses is used. In Republic of Croatia, in establishing of alfalfa crops, often, seed stored for three to four years is used (Čupić et al., 2005).

Microorganisms causing the root rot and wilting of alfalfa are main agents causing progressive decrease in productivity of alfalfa. Alfalfa root is exposed to fungal infection from sprouting of seed to development of seedlings and mature plants in the first year, and this continues in subsequent period, during the exploitation period of alfalfa fields. Various pathogenic fungi (Phytophthora spp., Pythium spp., Fusarium spp., Rhizoctonia spp., Colletotrichum spp., Verticillium spp., Sclerotinia spp. etc.) can cause specific types of root rot and rot in the above ground alfalfa stem and non-specific symptoms (lower growth, chlorosis and wilt) on above ground plant parts. Consequences of the incidence of such diseases have significant economical impact, exhibited through thinning of the crops, decrease in yield, in the quality of forage plants and longevity of alfalfa (Krnjaja et al., 2005). Many pathogens which cause disease of above ground parts of alfalfa and of root are transmitted by infected seed, so seed can represent very dangerous source of infection. Symptoms present on the alfalfa seed as well as seed of other forage plants caused by pathogenic organisms are manifested as seed rot and decay of seedlings, and plant root rot (Hanckok, 1983). Species of Fusarium species are considered to be the major alfalfa pathogens. Seed cover, cotyledons, young sprouts and leaf primordia of alfalfa can be occupied by hyphae from pathogenic fungi of the genus Fusarium (Chi et al., 1964). Most important seed pathogen is F. oxysporum f. sp. medicaginis which causes the disease of alfalfa of wilt type. It is transmitted by seed, and it is of epidemiological importance because it can have

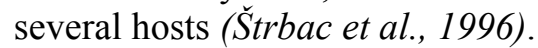

Diseases of alfalfa seed cause damage to greater or lesser degree, and consequences are losses in the quality and yield of plant mass. By using the healthy alfalfa seed for sowing, incidence and spreading of focal points from which certain diseases would spread to large areas is prevented, which is especially dangerous 
since it is perennial plant (Krnjaja and Lević, 2005). In addition to good health condition, it is very important that the seed is characterized by the ability to hold until next vegetative season, for the purpose of preservation of biodiversity which is increasingly under threat of fast progress of science (Gatarić et al., 2010).

Because of the risk from spreading of alfalfa diseases through infected seed, it is very important to use only high quality and healthy seed for sowing. Therefore, in this study, the microbiological quality and germination of seed, 24 and 108 months old seed, of six commercial domestic alfalfa cultivars was analyzed.

\section{Materials and Methods}

Material. Study was carried out in the Microbiological laboratory of the Institute for Animal Husbandry (Zemun-Belgrade) during October 2010. Initial material used in this study was seed of six alfalfa cultivars (K-22, K-23, K-28, NS Banat ZMS II, NS Mediana ZMS V and Zaječarska 83). Seed was produced in 2001 (seed age 108 months) and in 2009 (seed age 24 months). Older and younger seed was kept in paper bags in conditions with room temperature and low relative air humidity (50-60\%). Germination ability of older and younger seed, mass of 1000 seeds and moisture content were determined according to standard method ISTA (2008).

Isolation of fungi. Isolation of fungi was done according to standard phytopathological methods. For isolation of fungi, water agar was used (2\%) (WA). $\mathrm{NaCl}(0.85 \%)$ was added to WA to prevent germination of seed. Seed was disinfected using $10 \%$ of sodium hypochlorite solution $(\mathrm{NaOCl})$ for five minutes, and subsequently rinsed in sterile distilled water and dried on filter paper. 10 seeds of each cultivar were cultivated in Petri dish Ø100. In the analysis of the presence of pathogenic fungi, total of 400 older and 400 younger seeds of each cultivar were used. The cultivated seeds in Petri dishes were incubated seven days in thermostat at temperature of $25^{\circ} \mathrm{C}$.

Microscopic examination of developed fungi colonies around seed, and based on morphology of conidia, fungi genera were identified according to Nelson et al. (1983), Burgess et al. (1994) and Watanabe (1994).

\section{Results}

Based on the study of the germination ability of alfalfa seed it was established that all tested cultivars had higher germination ability of younger seed compared to older seed. Seed germination ability, in average for all cultivars, was higher in seed stored for 24 months $(87.7 \%)$ compared to seed stored for 108 months $(68.2 \%)$. The highest germination ability, in average for seed age, was established in cultivar NS Banat (93.0), and the lowest in cultivar K-28 (31.5\%). In 
average for all cultivars, mass of 1000 older seeds $(2.1 \mathrm{~g})$ showed no significant differences compared to mass of 1000 younger seeds $(2.0 \mathrm{~g})$. In average for seed age, mass of 1000 seeds was the highest in cultivar NS Mediana $(2.16 \mathrm{~g})$, and the lowest in cultivar K-28 (1.97 g). Seed moisture content in average for all cultivars showed no significant difference between older (8.25\%) and younger seeds $(8.19 \%)$. Seed moisture content, in average for seed age, was the highest in cultivar NS Mediana (8.42\%), and the lowest in cultivar K-28 (7.85\%) (Table 1).

Table 1. Seed germination ability, mass of 1000 seeds and seed moisture content in alfalfa seeds of different age

\begin{tabular}{|l|c|c|c|c|c|c|c|c|c|c|}
\hline \multirow{2}{*}{ Alfalfa cultivar } & \multicolumn{8}{|c|}{ Germination ability (\%) } & \multicolumn{7}{c|}{ Mass of 1000 seeds (g) } & \multicolumn{3}{c|}{ Seed moisture content (\%) } \\
\cline { 2 - 11 } & \multicolumn{8}{|c|}{ Seed age or year of production } \\
\hline & 2001 & 2009 & $\mathrm{M}$ & 2001 & 2009 & $\mathrm{M}$ & 2001 & 2009 & $\mathrm{M}$ \\
\hline K-22 & 63.0 & 92.0 & 77.5 & 1.97 & 2.09 & 2.03 & 8.28 & 8.13 & 8.20 \\
\hline K-23 & 73.0 & 95.0 & 84.0 & 2.26 & 1.91 & 2.09 & 8.49 & 7.88 & 8.19 \\
\hline K-28 & 6.0 & 57.0 & 31.5 & 1.89 & 2.04 & 1.97 & 7.89 & 7.81 & 7.85 \\
\hline NS Banat & 88.0 & 98.0 & 93.0 & 2.18 & 2.00 & 2.09 & 8.32 & 8.38 & 8.35 \\
\hline NS Mediana & 85.0 & 94.0 & 89.5 & 2.13 & 2.16 & 2.14 & 8.28 & 8.56 & 8.42 \\
\hline Zaječarska-83 & 94.0 & 90.0 & 92.0 & 2.18 & 1.82 & 2.00 & 8.24 & 8.37 & 8.30 \\
\hline M & 68.2 & 87.7 & 77.9 & 2.10 & 2.00 & 2.05 & 8.25 & 8.19 & 8.22 \\
\hline
\end{tabular}

Based on morphology of colonies and conidia, seven fungi genera have been identified: Alternaria, Aspergillus, Cladosporium, Fusarium, Penicillium, Rhizopus, Stemphylium and sterile mycelia. Based on comparison of the presence of number of genera in older and younger seeds, more fungi genera were established in younger seeds of cultivars K-22, K-23, NS Banat, NS Mediana and Zaječarska 83, compared to K-28 where more fungi genera was established in older seeds. Presence of identified fungi genera ranged from $0 \%$ do $6.5 \%$. Alternaria species were present with $0 \%$ on older seeds of cultivars K-22, K-23, NS-Banat, NS-Mediana and Zaječarska 83 , with $0.25 \%$ on older seeds of cultivar K-28, with $0.5 \%$ on younger seeds of cultivars K-28 and NS Mediana, with $0.75 \%$ on younger seed of K-22 and with $1.25 \%$ on younger seeds of cultivars K-23 and NS Banat. Presence of Aspergillus species ranged from 0\% (older and younger seed of K-22, K-23, K-28, NS Banat and Zaječarska 83 and older seed of NS Mediana) to $0.25 \%$ (younger seed of NS Mediana). Cladosporium species were present with $0 \%$ (older seed of K-23, NS Mediana and Zaječarska 83 and younger seed K-28), 0.25\% (younger seed of NS Mediana), 0.5\% (older seed of K-23, K-28 and NS Banat), 1\% (younger seed of K-23 and NS Banat) and 6.5\% (younger seed of K-22). Presence of Fusarium spp. was established only on younger seed of cultivar K-22 (0.25\%). In other cultivars, on seed of different age, the presence of this fungi genus was not established. Penicillium species were present with $0 \%$ (older and younger seed of K-23, NS Mediana and Zaječarska 83, older seed of K-28 and younger seed of NS Banat), $0.25 \%$ (older and younger seed of K-22), $0.5 \%$ (younger seed of K-28) and $1.75 \%$ (older seed of cultivar NS Banat). Rhizopus species were present with $0 \%$ 
(older and younger seed of cultivars K-22, K-23, NS Banat and NS Mediana and older seed of Zaječarska 83 ), $0.25 \%$ (older seed of K-28) and $0.5 \%$ (younger seed of cultivars K-28 and Zaječarska 83). Stemphylium species were not present on older and younger seed of cultivars K-28 and Zaječarska 83, older seed of cultivars K-22, K-23, NS Banat and NS Mediana. On the other hand, Stemphylium species were present with $0.25 \%$ on younger seed of cultivars K-22, K-23, NS Banat and NS Mediana. Sterile mycelia was present with $0 \%$ (older and younger seed of cultivar NS Mediana, older seed of NS Banat and Zaječarska 83 and younger seed of K-28), $0.25 \%$ (older seed of K-23, K-28), $0.5 \%$ (older seed of K-22 and younger seed of Zaječarska 83), 1\% (younger seed of K-23), 1.75\% (younger seed of NS Banat) and 4.5\% (younger seed of K-22) (Table 2).

Table 2. Incidence of fungi genera on seed of different age of six alfalfa cultivars

\begin{tabular}{|c|c|c|c|c|c|c|c|c|c|c|c|c|}
\hline \multirow{5}{*}{ Fungi genus } & \multicolumn{12}{|c|}{ Alfalfa cultivar } \\
\hline & \multicolumn{2}{|c|}{$\mathrm{K}-22$} & \multicolumn{2}{|c|}{$\mathrm{K}-23$} & \multicolumn{2}{|c|}{ K-28 } & \multicolumn{2}{|c|}{ NS Banat } & \multicolumn{2}{|c|}{ NS Mediana } & \multicolumn{2}{|c|}{ Zaječarska-83 } \\
\hline & \multicolumn{12}{|c|}{ Year of production of seed } \\
\hline & 2001 & 2009 & 2001 & 2009 & 2001 & 2009 & 2001 & 2009 & 2001 & 2009 & 2001 & 2009 \\
\hline & \multicolumn{12}{|c|}{ Incidence (\%) } \\
\hline Alternaria & 0 & 0.75 & 0 & 1.25 & 0.25 & 0.5 & 0 & 1.25 & 0 & 0.5 & 0 & 1 \\
\hline Aspergillus & 0 & 0 & 0 & 0 & 0 & 0 & 0 & 0 & 0 & 0.25 & 0 & 0 \\
\hline Cladosporium & 0 & 6.5 & 0.5 & 1.0 & 0.5 & 0 & 0.5 & 1.0 & 0 & 0.25 & 0 & 0 \\
\hline Fusarium & 0 & 0.25 & 0 & 0 & 0 & 0 & 0 & 0 & 0 & 0 & 0 & 0 \\
\hline Penicillium & 0.25 & 0.25 & 0 & 0 & 0 & 0.5 & 1.75 & 0 & 0 & 0 & 0 & 0 \\
\hline Rhizopus & 0 & 0 & 0 & 0 & 0.25 & 0.5 & 0 & 0 & 0 & 0 & 0 & 0.5 \\
\hline Stemphylium & 0 & 0.25 & 0 & 0.25 & 0 & 0 & 0 & 0.25 & 0 & 0.25 & 0 & 0 \\
\hline Sterile mycelia & 0.5 & 4.5 & 0.25 & 1.0 & 0.25 & 0 & 0 & 1.75 & 0 & 0 & 0 & 0.5 \\
\hline
\end{tabular}

\section{Discussion}

Commercial alfalfa seed is very often stored for period of two or more years prior to its use. During the period of storage of alfalfa, the changes in the germination energy, germination ability, abnormal seedlings, hard or dead seed occur. The most important factors influencing these changes are seed age, air temperature and humidity during storage (Čupić et al., 2005). In our study, significant difference was established in the germination ability between older and younger seed in all tested alfalfa cultivars. Considering the average values for all tested cultivars, older seed had significantly lower germination ability $(68.2 \%)$ compared to younger seed $(87.7 \%)$.

Seed is very suitable substrate for maintenance and spreading of pathogenic disease-causing agents. Therefore, health control of seeds is necessary as preventive measure in suppression of spreading of economically important alfalfa diseases. In Serbia, there are insufficient data on health condition of alfalfa seed in relation to presence of important pathogenic fungi. In previous studies, Lukić and 
Purar (1996), in the analysis of the health condition of seed of 10 domestic alfalfa cultivars, established the presence of fungi of genera Alternaria (3-48\%), Botrytis $(0-10 \%)$ and Fusarium (0-8\%). In the analysis of the health condition of seed of six Serbian alfalfa cultivars, in treatment where seed was disinfected in sodium hypochlorite, Krnjaja et al. (2003) established the presence of fungi of genera Alternaria (0-5\%), Cladosporium (0-1\%), Fusarium (0-2\%) and Stemphylium (0$1 \%)$. Of Fusarium spp. the following were isolated: F. sporotrichioides $(1 \%)$ on seed of cultivar K-23 and $F$. verticillioides (2\%) on seed of cultivar Zaječarska 83. Species Stemphylium botryosum (1\%) was isolated on the seed of cultivar Zaječarska 83.

According to Regulation on health examination of crops and facilities for production of seed, seedlings and seed material and health examination/analysis of seed, seedlings and seed material (Službeni list SRJ, 1999), the following level of alfalfa seed infection is allowed in (\%): Colletotrichum spp. (1\%), Fusarium spp. (2\%), Kabatiella caulivora (2\%), Sclerotinia spp. (0\%), Stemphylium spp. (1\%), Verticillium albo atrum (1\%), alfalfa mosaic virus (0\%), Cuscuta spp. (0\%). According to above mentioned Rulebook, results obtained in this study in regard to presence of pathogenic fungi species indicate good health status of seed of different age of all tested cultivars. The storage conditions (room temperature and low relative air humidity), as well as low seed moisture content, probably influenced the good health quality of investigated seed of alfalfa cultivars.

\section{Conclusion}

24 month old alfalfa seed had better germination ability compared to 108 month old seed. There was no statistically significant difference in the mass of 1000 seeds and seed moisture content between alfalfa seed of different age. In average for seed age, cultivar NS Banat had the highest germination ability, and cultivar NS Mediana the greatest mass of 1000 seeds and seed moisture content.

In studied seed material, seven fungi genera were identified: Alternaria, Aspergillus, Cladosporium, Fusarium, Penicillium, Rhizopus, Stemphylium and sterile mycelia. Cultivars K-22, K-23, NS Banat, NS Mediana and Zaječarska 83 had more fungi genera present on their seed produced in 2009, contrary to cultivar $\mathrm{K}-28$ where more fungi genera was identified on seed produced in 2001.

\section{Acknowledgment}

Research was financed by the Ministry of Education and Science, Republic of Serbia, project TR-31053. 


\title{
Učestalost patogenih gljiva na lucerkinom semenu različite starosti
}

\author{
V. Krnjaja, J. Lević, D. Ivanović, V. Mandić, Z. Tomić, Z. Bijelić, G. Marinkov
}

\section{Rezime}

U radu je proučavano prisustvo patogenih vrsta gljiva na semenu šest sorti lucerke (K-22, K-23, K-28, NS Banat, NS Mediana i Zaječarska 83) različite starosti semena (24 meseca i 108 meseci). Kod ispitivanih sorti, osim kod sorte K28, na starijem semenu identifikovan je manji broj rodova gljiva u odnosu na mlađe seme. Identifikovano je sedam rodova gljiva, Alternaria, Aspergillus, Cladosporium, Fusarium, Penicillium, Rhizopus, Stemphylium i sterilna micelija sa prisustvom od 0 do $6,5 \%$. Alternaria vrste identifikovane su na mlađem semenu sa $0,5 \%$ kod sorata K-28 i NS Mediana, $0,75 \%$ kod K-22, 1\% kod Zaječarska 83 i $1,25 \%$ kod NS Banat. Kod sorte K-28 Alternaria vrste identifikovane su sa $0,25 \%$ na starijem semenu. Aspergillus vrste identifikovane su sa $0,25 \%$ samo kod mlađeg semena sorte NS Mediana. Cladosporium vrste identifikovane su na mlađem semenu sa $0,25 \%$ (NS Mediana), $1 \%$ (K-23 i NS Banat) i 6,5\% (K-22), a na starijem semenu sa $0,5 \%$ (K-23, K-28 i NS Banat). Rod Fusarium identifikovan je sa $0,25 \%$ na mlađem semenu kod sorte K-22. Rod Penicillium identifikovan je od $0,25 \%$ (K-22) do 0,5\% (K-28) na mlađem semenu i od 0,25\% (K-22) do 1,75\% (NS Banat) na starijem semenu. Rod Rhizopus identifikovan je kod sorte K-28 i na mlađem $(0,5 \%)$ i na starijem semenu $(0,25 \%)$, a kod sorte Zaječarska 83 samo na mlađem semenu sa $0,5 \%$. Sterilna micelija identifikovana je na mlađem semenu kod sorti K-22 (4,5\%), NS Banat (1,75\%), K-23 (1,0\%) i Zaječarska $83(0,5 \%)$, a na starijem semenu kod sorti K-23 i K-28 sa po $0,25 \%$ i K-22 sa $0,5 \%$. Rod Stemphylium identifikovan je sa $0,25 \%$ samo na mlađem semenu sorti K-22, K-23, NS Banat i NS Mediana. Rezultati ovih analiza ukazuju na povoljno zdravstveno stanje semena različite starosti kod svih ispitivanih sorti lucerke, posebno u odnosu na ekonomski značajne rodove gljiva Fusarium i Stemphylium.

\section{References}

BURGESS L.W., SUMMERELL B.A., BULLOCK S., GOTT K.P., BACKHOUSE D. (1994): Laboratory manual for Fusarium research. Third edition. Fusarium Research Laboratory, Department of Crop Sciences, University of Sydney and Royal Botanic Gardens, Sydney, 133 p.

CHI C.C., CHILDERS W.R., HANSON E.W. (1964): Penetration and subsequent development of three Fusarium species in alfalfa and red clover. Phytopathology, 54, 434-437. 
ČUPIĆ T., POPOVIĆ S., GRLJUŠIĆ S., TUCAK M., ANDRIĆ L., ŠIMIĆ B. (2005): Effect of storage time on alfalfa seed quality. Journal of Central European Agriculture, 6, 1, 65-68.

GATARIĆ Đ., KOVAČEVIĆ Z., ĐURIĆ B., RADIĆ V., LAKIĆ Ž. (2010): Genetic resources of forage legumes and grasses in Republic of Srpska. Biotechnology in Animal Husbandry, 26, specc. issue, 1-6.

HANCOCK J.G. (1983): Seedling diseases of alfalfa in California. Plant Disease, 67, 1203-1208.

INTERNATIONAL SEED TESTING ASSOCIATIONS (ISTA) (2008): International rules for seed testing. Basserdorf, Switzerland (2008).

KARAGIĆ Đ., KATIĆ S., VASILJEVIĆ S., MILIĆ D. (2007): Semenarstvo lucerke u Vojvodini. Zbornik radova, Institut za ratarstvo i povrtarstvo, Novi Sad, 44, 87-106.

KRNJAJA V. (2005): Uloga Fusarium spp. u kompleksu prouzrokovača truleži korena lucerke (Medicago sativa L.). Doktorska disertacija. Poljoprivredni fakultet, Zemun, Univerzitet u Beogradu, 1-124.

KRNJAJA V., LEVIĆ J. (2005): Patogeni semena i klijanaca licerke i deteline i mere suzbijanja. Biljni lekar/Plant Doctor, XXXIII, 5, 583-589.

KRNJAJA V., LEVIĆ J., IVANOVIĆ M., TOMIĆ Z. (2003): Fusarium species associated with seeds of alfalfa cultivars. Czech Journal of Genetic and Plant Breeding, 39, special issue, 275-278.

KRNJAJA V., IVANOVIĆ M., LEVIĆ J., TOMIĆ Z. (2005): Bolesti korena lucerke i mere suzbijanja patogena. Biljni lekar/Plant Doctor, XXXIII, 5, 565-576.

LUKIĆ D., PURAR B. (1996): Ekonomski značajne bolesti raznih tipova lucerke. Biljni lekar, XXIV (4), 334-337.

NELSON P.E., TOUSSOUN T.A., MARASAS W.F.O. (1983): Fusarium Species. An illustrated manual for identification. The Pennsylvania State University Press, University Park and London, $193 \mathrm{p}$.

O'ROURKE C.J., MILLAR R.L. (1966): Root rot and root microflora of alfalfa as affected by potassium nutrition, frequency of cutting, and leaf infection. Nature, 220, 1040-1046.

SLUŽBENI LIST SRJ (1999): Pravilnik o zdravstvenom pregledu useva i objekata za proizvodnju semena, rasada i sadnog materijala i zdravstvenog pregleda semena, rasada i sadnog materijala.

STATISTIČKI GODIŠNJAK SRBIJE (2010): Republika Srbija. Republički Zavod za informatiku i statistiku. Beograd, 209 p.

ŠTRBAC P., KONSTATINOVIĆ B., KLOKOČAR-ŠMIT Z., DRAŽIĆ D. (1996): Zaštita lucerke od štetočina, bolesti i korova. Forum, Novi Sad.

WATANABE T. (1994): Pictorial atlas of soil and seed fungi: morphologies of cultured fungi and key to species. Lewis Publishers, Boca Raton, Boston, London, Washington D.C., $410 \mathrm{p}$. 